\title{
Therapeutic use of an antibiotic-resistant Bifidobacterium preparation in men exposed to high-dose $\gamma$-irradiation
}

\author{
V. M. KORSCHUNOV, V. V. SMEYANOV $\ddagger$ B. A. EFIMOV, N. P. TARABRINA, A. A. IVANOV* and \\ A. E. BARANOV*
}

Department of Microbiology, Russia State Medical University, ul. Ostzovitjanova 1, Moscow 117869 and *Institute for Biophysics, ul. Zhyropysnaya 16. Moscow 123182, Russia

\begin{abstract}
Five men received high-dose, uneven, whole-body $\gamma$-irradiation by accidental exposure to an unshielded ${ }^{137} \mathrm{Cs}$ source. Analysis of the faeces 9-12 days post-irradiation showed low numbers of anaerobes and high counts of enterobacteria and staphylococci in four of the patients and total viable counts of $<10^{3} / \mathrm{g}$ in one. All five were treated with systemic ampicillin and gentamicin and oral nystatin commencing 4-7 days after irradiation. Three of the patients were also treated orally with a suspension of an antibiotic-resistant strain of Bifidobacterium longum for 30 days commencing 10-12 days post-irradiation. At 3 weeks post-irradiation, $B$. longum had appeared in their faecal flora and total anaerobe counts exceeded those of facultative and obligate aerobes. At 4 weeks and 5-7 weeks post-irradiation, this normalisation of the faecal flora continued. In contrast, in the two patients who received a placebo the faecal flora was dominated by enterobacteria (Klebsiella, Enterobacter and Serratia spp.) showing multiple antibiotic resistance 3 weeks post-irradiation. These potential opportunist pathogens were not isolated from the $B$. longum-treated group. Only one patient in the control group survived beyond 3 weeks; he continued to show high faecal counts of enterobacteria and staphylococci and low counts of obligate anaerobes. 'Probiotic' treatment with this antibiotic-resistant strain of $B$. longum may be of benefit in the treatment of radiation sickness, aiding normalisation of the faecal flora and inhibiting colonisation and overgrowth with opportunist pathogens.
\end{abstract}

\section{Introduction}

Animal studies have shown that whole-body and localised abdominal exposure to ionising radiation disturbs the intestinal ecology, with decrease in the numbers of anaerobes, particularly bifidobacteria and lactobacilli, and increase in the numbers of aerobic and facultative organisms, particularly enterobacteria, enterococci, staphylococci and yeasts [1-7]. Potentially pathogenic organisms of the genera Klebsiella, Proteus, Enterobacter, Citrobacter and Pseudomonas colonise the small intestine [8] and adhere to the intestinal wall [9], and the proportion of enterotoxigenic enterobacteria increases [10]. Organisms from this altered flora may

Received 22 Aug. 1994; revised version received 21 April 1995; accepted 21 July 1995.

‡Corresponding author: V. V. Smeyanov. translocate to the bloodstream, causing post-irradiation sepsis [11-14].

In man, the early LD50 (death at $\leqslant 60$ days) for ionising radiation is suggested to be 4.5 Gray (Gy; $c$. $450 \mathrm{rad}$ ) [15]. Treatment comprises antibiotic prophylaxis, administration of immunostimulants, transfusion and electrolyte and fluid loss replacement. Bone marrow transplantation is regarded as essential in patients receiving supra-lethal irradiation [15-17]. Intensive therapy of patients irradiated with near-lethal dosages in the Chernobyl accident gave high survival rates [16-19]. Nonetheless, whole-body irradiation at $\geqslant 10 \mathrm{~Gy}$ is considered supra-lethal, with a mortality of $100 \%$ within 8-16 days [17]. Changes in the human faecal microflora after irradiation at $2.1-8.7 \mathrm{~Gy}$ in the Chernobyl accident were similar to those seen in animal models; aerobic and facultative species became 
predominant, bifidobacteria almost disappeared and lactobacilli were significantly reduced (Korschunov $e t$ al., unpublished data).

Oral treatment of acute radiation sickness with live bifidobacteria and lactobacilli (probiotic treatment) increased median survival times in mice exposed to up to $8 \mathrm{~Gy}$ doses of $\gamma$-irradiation, but not in rats exposed to $>8.5$ Gy [20]. The beneficial effects in irradiated mice correlated with normalisation of their intestinal microflora [5]. Combined therapy with broadspectrum antibiotics and oral bifidobacteria was more effective than antibiotic treatment alone, which again correlated with normalisation of the flora [21]. In mice irradiated at $7 \mathrm{~Gy}$, treatment with ampicillin, kanamycin or gentamicin, combined with oral treatment with a Bifidobacterium strain resistant to these antibiotics $(B$. longum D4a200) gave significantly increased survival compared to antibiotic treatment alone $[22,23]$. The advantage of probiotic treatment with antibiotic-resistant bifidobacteria is that it may be used concurrently with antibiotic treatment. The strain described here has been used successfully in the treatment of ulceronecrotic enterocolitis in children, acute dysentery and acute intestinal diseases of obscure aetiology [24-26]. This paper outlines the results of treatment with $B$. longum $\mathrm{D} 4 \mathrm{a} 200$ in patients accidentally exposed to high doses of $\gamma$-irradiation.

\section{Materials and methods}

\section{Patients}

Five men aged 19-20 years received high doses of whole-body, external, uneven $\gamma$-irradiation from a ${ }^{137} \mathrm{Cs}$ source, a small $(1 \mathrm{~cm} \times 3 \mathrm{~cm})$ metal cylinder which had been removed from its shielding and left with no indication of its hazardous nature. Each of the patients handled the source and carried it in the lower side pocket of their clothing for 2-4h [27]. Localised dosages to the lower abdomen, estimated by reconstructive physical methods and biological methods $[16,19]$, were in the mid-lethal range $75-110 \mathrm{Krad}$, and overall dosages, estimated from the frequency of dicentric bone marrow-derived haemopoetic cells, were in the mid-lethal range (Table 1). The incident was detected and prophylactic therapy (intramuscular gentamicin 3-5 mg/kg/day; intravenous ampicillin $1500 \mathrm{mg} /$ day; oral nystatin $2000000 \mathrm{iu} /$ day) commenced 4-7 days after exposure. Faecal specimens were taken 9-12 days after exposure. Probiotic (three patients) or placebo treatment (two patients) commenced the next day, and further faecal specimens were taken 10-11, 18-21 and 27-30 days after this, i.e., 19-24, 28-34 and $37-40$ days after exposure.

\section{Probiotic and placebo preparations}

A variant of $B$. longum D4a200 resistant to gentamicin $(2200 \mathrm{mg} / \mathrm{L})$, kanamycin $(50200 \mathrm{mg} / \mathrm{L})$, monomycin $(2200 \mathrm{mg} / \mathrm{L})$ and ampicillin $(220 \mathrm{mg} / \mathrm{L})[28]$, stored as a lyophilised culture, was grown on Blaurock's medium [29] at $37^{\circ} \mathrm{C}$ for $24 \mathrm{~h}$ in an atmosphere of $\mathrm{H}_{2} 10 \%, \mathrm{CO}_{2}$ $5 \%, \mathrm{~N}_{2} 85 \%$. Cells were harvested by centrifugation at $1000 \mathrm{~g}$ and resuspended in sterile milk at a concentration of c. $10^{9} \mathrm{cfu} / \mathrm{ml}$. The placebo comprised uninoculated sterile milk. Treatment was oral, $10 \mathrm{ml} /$ day for 30 days.

\section{Microbiological studies}

Fresh faecal specimens were collected in sterile glass tubes filled with $\mathrm{CO}_{2}$, placed on ice and sent immediately to the laboratory. There, they were placed in an anaerobe cabinet (Hirosawa, Japan) and diluted in pre-reduced Hanks's Balanced Salts Solution. Counts of enterobacteria, staphylococci and enterococci were estimated by plating on Endo-Agar (Serva, Germany), Staphylococcus Agar (Difco) and Enterococcus Agar (Serva) incubated aerobically at $37^{\circ} \mathrm{C}$ for $48 \mathrm{~h}$. Lactobacillus counts were estimated on MRS Agar (Difco) incubated in $\mathrm{CO}_{2}$ at $37^{\circ} \mathrm{C}$ for $48 \mathrm{~h}$ and bifidobacteria counts in $8-\mathrm{ml}$ tubes of pre-reduced Blaurock's agar $0.75 \%$ incubated anaerobically for 4 days. Counts of other obligate anaerobes were estimated on blood agar, incubated anaerobically for 4 days at $37^{\circ} \mathrm{C}$ [30]. Viable counts were recorded as $\log _{10} \mathrm{cfu} / \mathrm{g}$ wet weight of faeces. Isolates were identified by standard methods [31], or in the appropriate API20 system. Susceptibilities of enterobacteria were determined by disk-diffusion tests [31].

\section{Results}

The composition of the faecal flora of the patients at 912 days post-irradiation is compared with that expected in healthy subjects $[32,33]$ in Table 2 . The counts and incidence of lactobacilli were much lower than in healthy subjects, bifidobacteria were isolated from only

Table 1. Radiation dose and survival of patients

\begin{tabular}{|c|c|c|c|c|c|}
\hline \multirow[b]{2}{*}{ Patient } & \multicolumn{2}{|c|}{$\begin{array}{l}\text { Estimated dosage } \\
\text { (Krad) to }\end{array}$} & \multirow{2}{*}{$\begin{array}{c}\text { Estimated } \\
\text { total dose } \\
\text { (Grays) }\end{array}$} & \multirow{2}{*}{$\begin{array}{l}\text { Survival post- } \\
\text { irradiation } \\
\text { (days) }\end{array}$} & \multirow[b]{2}{*}{ Cause of death } \\
\hline & hands & abdomen & & & \\
\hline A & 12 & 105 & 4.2 & 105 & Bacterial sepsis \\
\hline B & 1 & 75 & 4.8 & 132 & Intestinal syndrome and burns \\
\hline $\mathrm{C}$ & 6 & 100 & 3.4 & 699 & Infectious complications \\
\hline $\mathrm{D}$ & 115 & 110 & 2.8 & 127 & Pulmonary embolus \\
\hline $\mathrm{E}$ & 29 & 950 & 4.8 & 25 & Intestinal syndrome and tissue necrosis \\
\hline
\end{tabular}


one patient $(E)$, and no anaerobic gram-negative bacilli were isolated. Diversity of the flora was markedly reduced. No organisms were isolated from the faeces of patient $B$. In two patients ( $C$ and $E$ ), counts were $<1000 / g$ wet weight for all but a single group of organisms. Only two patients (A and D) yielded a diverse flora, but in both the balance of organisms was clearly abnormal, with enterobacteria 10 -fold in excess of normal and a massive excess of staphylococci.

Subsequently (Tables 2 and 3), changes in the flora differed considerably between the probiotic-treated (patients $\mathrm{A}-\mathrm{C}$ ) and placebo-treated (patients $\mathrm{D}$ and $\mathrm{E}$ ) groups. Bifidobacteria were isolated from 10-11 days onward (patients A and B) or at 27-30 days (C) after probiotic treatment commenced. In contrast, patients D and $\mathrm{E}$ showed a decrease in bifidobacteria during placebo treatment. The population of lactobacilli decreased with time in all patients except $\mathrm{C}$, who showed counts comparable to normal subjects at 27-30 days. Total anaerobe counts fluctuated markedly during treatment, but were consistently higher in the probiotictreated group. This contrasted with the pre-treatment samples, when these patients showed lower total anaerobe counts than patients $\mathrm{D}$ and $\mathrm{E}$.

No enterobacteria or enterococci were isolated from the probiotic-treated patients at days $10-11$, in contrast to the placebo group, where enterobacteria dominated the flora, and enterococcal counts were $c .10^{5} / \mathrm{g}$. At days

Table 2. Faecal flora of the irradiated patients during the course of treatment, contrasted with that of normal subjects

\begin{tabular}{|c|c|c|c|c|c|c|c|c|}
\hline \multirow[b]{2}{*}{ Patient* } & \multirow[b]{2}{*}{ Day } & \multicolumn{7}{|c|}{$\log _{10}$ viable count/g wet weight of faeces for } \\
\hline & & bifidobacteria & lactobacilli & $\begin{array}{c}\text { other } \\
\text { lactic acid } \\
\text { bacteria }\end{array}$ & $\begin{array}{c}\text { other } \\
\text { anaerobes } \dagger\end{array}$ & staphylococci & enterococci & enterobacteria $\dagger$ \\
\hline $\mathbf{A}$ & -1 & $<3.0$ & 8.9 & $<3.0$ & $<3.0$ & 8.9 & 7.2 & $10.2 \mathrm{Ec}$ \\
\hline B & -1 & $<3.0$ & $<3.0$ & $<3.0$ & $<3.0$ & $<3.0$ & $<3.0$ & $<3.0$ \\
\hline $\mathrm{C}$ & -1 & $<3.0$ & 5.0 & $<3.0$ & $<3.0$ & $<3.0$ & $<3.0$ & $<3.0$ \\
\hline D & $-i$ & $<3.0$ & 6.9 & 9.7 & $<3.0$ & 9.5 & 7.2 & 9.7 Ko, 9.4 En \\
\hline $\mathrm{E}$ & -1 & 7.0 & $<3.0$ & $<3.0$ & $<3.0$ & $<3.0$ & $<3.0$ & $<3.0$ \\
\hline A & $10-11$ & 5.5 & 5.7 & $<3.0$ & 4.1 Ps & $<3.0$ & $<3.0$ & $<3.0$ \\
\hline B & $10-11$ & 5.0 & $<3.0$ & 8.3 & 9.3 Pc & 7.9 & $<3.0$ & $<3.0$ \\
\hline $\mathrm{C}$ & $10-11$ & $<3.0$ & $<3.0$ & $<3.0$ & $<3 \cdot 0$ & $<3.0$ & $<3.0$ & $<3.0$ \\
\hline D & $10-11$ & $<3.0$ & $<3.0$ & 4.6 & $<3.0$ & $<3.0$ & 4.3 & $7.9 \mathrm{Pm}$ \\
\hline E & $10-11$ & $<3.0$ & $<3.0$ & $<3.0$ & $8.9 \mathrm{Ac}$ & $<3.0$ & 5.8 & $9.2 \mathrm{Ko}$ \\
\hline A & $18-21$ & 5.6 & $<3.0$ & 4.3 & $<3.0$ & 6.6 & 3.3 & $9.5 \mathrm{Ko}$ \\
\hline B & $18-21$ & 5.3 & $<3.0$ & $<3.0$ & $<3.0$ & 5.0 & 4.0 & $7.8 \mathrm{Ec}, 7.9 \mathrm{Ko}$ \\
\hline D & $18-21$ & $<3.0$ & $<3.0$ & $<3.0$ & $<3 \cdot 0$ & 8.2 & 6.5 & $8.1 \mathrm{En}, 7.5 \mathrm{Se}$ \\
\hline A & $27-30$ & 7.4 & $<3.0$ & 7.9 & $<3.0$ & 7.9 & 6.0 & 8.5 Ko \\
\hline B & $27-30$ & 7.7 & $<3.0$ & 8.1 & $<3.0$ & 8.0 & 8.3 & $9.1 \mathrm{Ec}, 8.6 \mathrm{Ko}$ \\
\hline $\mathrm{C}$ & $27-30$ & 7.3 & 8.2 & 8.9 & $<3.0$ & 7.9 & 7.8 & $8.3 \mathrm{Ec}, 8.0 \mathrm{Ko}$ \\
\hline $\mathrm{D}$ & $27-30$ & $<3.0$ & $<3.0$ & 6.0 & $<3.0$ & 5.8 & 4.3 & $8.4 \mathrm{En}$ \\
\hline \multicolumn{9}{|c|}{ In normal subjectsł } \\
\hline \multicolumn{2}{|c|}{ Incidence } & $100 \%$ & $100 \%$ & & & $47 \%$ & $100 \%$ & $98 \%$ \\
\hline \multicolumn{2}{|c|}{ Mean counts } & 8.6 & 6.9 & & & 3.6 & 7.0 & 8.9 \\
\hline
\end{tabular}

*No samples were available for patient $\mathrm{C}$ at days $18-21$. Patient $\mathrm{E}$ died at day 25 after exposure.

†Ac, Actinomyces sp.; Ec, Escherichia coli; En, Enterobacter cloacae; Ko, Klebsiella ozenae; Pc, Peptococcus sp.; Pm, Proteus mirabilis; Ps, Peptostreptococcus sp.; Se, Serratia liquefaciens.

†See Lizko and Shilov [32] and Finegold, Sutter and Matheisen [33]. Figures for other lactic acid bacteria and other anaerobes were not available.

Table 3. Faecal flora of the probiotic-treated and placebo groups during the course of treatment

\begin{tabular}{|c|c|c|c|c|c|c|c|c|}
\hline \multirow[b]{3}{*}{ Bacteria } & \multicolumn{8}{|c|}{ Proportion of mean total viable count (\%) } \\
\hline & \multicolumn{4}{|c|}{ Placebo group at days } & \multicolumn{4}{|c|}{ Probiotic group at days } \\
\hline & Initial & $10-11$ & $18-21$ & $27-30$ & Initial & $10-11$ & $18-21$ & $27-30$ \\
\hline Bifidobacteria & 0.10 & 0.00 & 0.00 & 0.00 & 0.00 & 0.02 & 0.01 & 0.79 \\
\hline Lactobacilli & 0.04 & 0.00 & 0.00 & 0.00 & 3.44 & 0.02 & 0.00 & 5.72 \\
\hline Other lactic & & & & & & & & \\
\hline acid bacteria & 25.45 & 0.00 & 0.00 & 0.10 & 0.00 & 9.48 & 0.00 & 9.99 \\
\hline Other anaerobes & 22.91 & 28.79 & 0.00 & 0.00 & 0.00 & 86.69 & 0.00 & 0.00 \\
\hline Staphylococci & 15.27 & 0.00 & 52.81 & 76.64 & 34.37 & 3.79 & 0.87 & 11.80 \\
\hline Enterococci & 0.08 & 0.02 & 0.99 & 0.06 & 0.07 & 0.00 & 0.79 & 11.80 \\
\hline Enterobacteria & 36.14 & 71.19 & 46.21 & 23.19 & 62.11 & 0.00 & 98.33 & 59.91 \\
\hline Total anaerobes & 48.49 & 28.79 & 0.00 & 0.10 & 3.44 & 96.21 & 0.01 & 16.49 \\
\hline Total aerobes & 51.51 & 71.21 & 100.00 & 99.89 & 9.6 .56 & 3.79 & 99.99 & 83.51 \\
\hline Total bacteria (cfu/g) & $2.0 \times 10^{10}$ & $2.6 \times 10^{9}$ & $3.0 \times 10^{8}$ & $9.9 \times 10^{8}$ & $2.4 \times 10^{10}$ & $2.1 \times 10^{9}$ & $5.1 \times 10^{9}$ & $1.1 \times 10^{10}$ \\
\hline
\end{tabular}


10-11, three patients became transiently colonised with gram-positive anaerobes - peptococci, peptostreptococci or actinomycetes. By days 18-21 and 27-30, enterobacteria and enterococci were established in the flora of the probiotic-treated group. In all patients, the colonising enterobacteria were potential pathogens showing multiple antibiotic resistance patterns, including resistance to antibiotics other than those being used in prophylaxis. Staphylococci were found in patient B only at days $10-11$, but increased in numbers in all surviving patients. Aerobes constituted a consistently greater proportion of the faecal flora in the placebotreated group throughout the study.

\section{Discussion}

Early antimicrobial therapy is regarded as essential in the treatment of radiation sickness. The results presented here were undoubtedly affected by the antibiotic treatment instituted before the faecal flora could be sampled. Previous studies in mice and monkeys show that such treatment intensifies the post-irradiation disturbances in the intestinal microflora, and leads to selection of antibiotic-resistant strains [6]. Nonetheless, the changes described here are similar to those reported in irradiated animal models. The indigenous anaerobic organisms, especially bifidobacteria and lactobacilli, appear to be the most sensitive component of the flora, and depletion of this component is an indicator of postirradiation intestinal dysbacteriosis [6,34]. Another characteristic feature in animals is the large increase in enterobacteria, often involving species that are potential pathogens and are minor or infrequent proportions of the normal aerobic flora [8]. Unpublished data obtained in our laboratory for victims of the Chernobyl incident, and the results presented here support the picture of intestinal flora disturbances drawn from animal models.

The predominant organisms of the post-irradiation flora, enterobacteria, enterococci, staphylococci and, sometimes, Candida spp., are often those implicated in the local and systemic infections that usually follow severe radiation injury in man [19] and animals $[7,11,13,14]$. The high susceptibility of irradiated patients to infection may be explained by the pathway to systemic sites offered by the catastrophic radiation damage to the intestinal mucosa, the destruction of immune and cell-mediated systemic defences, and the extreme disturbance of the normal intestinal flora, which might otherwise offer resistance to overgrowth by these organisms $[35,36]$.

The role of bacteria in mortality may well not be limited to these overt infections. The major pathological change after supra-lethal ( $>10 \mathrm{~Gy}$ ) whole-body irradiation in man is the intestinal syndrome $[17,37]$, or 'gut death' with loss of fluids, proteins and electrolytes as the main cause of mortality. In mice, pre-irradiation gut decontamination significantly increases mean survival time and LD50/30 [5], as does post-irradiation administration of live bifidobacteria [20]. All 10 Chernobyl victims who received $>10$ Gy dosage died within 21 days despite intensive fluid, electrolyte and protein replacement therapy [19]. It is probable that components of the altered intestinal flora may exacerbate the post-irradiation damage to the intestine, contributing to mortality.

In animal models, prophylaxis with a broad-spectrum combination of antibiotics is less effective than selective gut decontamination with agents that have limited activity against the anaerobic components of the normal flora, but high activity against the aerobic components, such as the quinolone antibiotics $[34,38]$. However, gram-negative facultative aerobes are not the only organisms implicated in post-irradiation infection. Streptococci and Bacteroides spp. may also cause infection [39]. Additional prophylaxis with metronidazole or penicillin to cover Bacteroides spp. leads to increased rates of enterobacterial infection [7], while quinolone-glycopeptide prophylaxis has failed to prevent colonisation and infection with glycopeptideresistant enterococci [13]. It is possible that treatment with bifidobacteria of a suitable antibiotic-resistance pattern might suppress colonisation with these less frequently implicated pathogens, removing this disadvantage of selective prophylaxis with quinolone antibiotics.

Ionising radiation treatment alone [8], tends to select an antibiotic-resistant flora, and this is probably compounded by the selection pressure of the prophylactic treatment $[6,35,40]$. In this study, all of the enterobacteria isolated from day 14 after the start of antibiotic treatment showed multiple drug resistance.

Irradiation of these patients was uneven, affecting mainly the abdomen and hands. As a result, all of the patients described here developed the intestinal syndrome, with the exception of patient C. All three patients treated with the $B$. longum suspension survived for $>120$ days, whereas one patient in the control group survived for 127 days, and the other for 25 days. The delayed colonisation with antibioticresistant enterobacteria for the probiotic-treated patients may well have been a factor in the improved shortterm survival for this group.

We thank Academician L. A. Iljin, Director of the Institute for Biophysics, Moscow for organisational support.

\section{References}

1. Vincent JG, Veomett RC, Riley RF. Relation of the indigenous flora of the small intestine of the rat to post-irradiation bacteremia. $J$ Bacteriol 1955; 69: 38-44.

2. Kent TH, Osborne JW, Wende CM. Intestinal flora in wholebody and intestinal X-irradiated rats. Radiat Res 1968; 35: 635-651. 
3. Pinegin BV, Klemparskaia NN, Mal'tsev VN, Korshunov VM, Meretskov VV. [Quantitative patterns in changes in the intestinal microflora of irradiated mice.] $\mathrm{Zh}$ Mikrobiol Epidemiol Immunobiol 1977; (7) 88-94.

4. Mal'tsev VN, Pinegin BV, Korshunov VM. [Analysis of the changes in the intestinal microflora of irradiated mice.] Radiobiologiia 1977; 17: 524-529.

5. Korshunov VM, Kissina EV, Ikonnikova TB, Mal'tsev VN, Goncharova GI. [Effect of lactobacillus and bifidobacteria preparations on the intestinal microflora of mice irradiated with gamma quanta.] $Z$ h Mikrobiol Epidemiol Immunobiol 1980; (6) 47-57.

6. Pinegin BV. [Dysbacterioses of the intestine.] Moscow, Meditsina. 1984: 63-134.

7. Brook I, Ledney GD. Effect of antimicrobial therapy on the gastrointestinal bacterial flora, infection and mortality in mice exposed to different doses of irradiation. $J$ Antimicrob Chemother 1994; 33: 63-77.

8. Pinegin BV, Korshunov VM, Ikonnikova TB, Kissina EV. [Quantitative and qualitative characteristics of the representatives of the Enterobacteriaceae family in postradiation intestinal dysbacteriosis.] Zh Mikrobiol Epidemiol Immunobiol 1980; (8) 46-50.

9. Korshunov VM, Ikonnikova TB, Kissina EV, Tarabrina NP Pinegin BV. [Microflora study of the intestinal cavity and mucosa normally and after gamma irradiation.] $\mathrm{Zh}$ Mikrobiol Epidemiol Immunobiol 1980; (9) 65-70.

10. Korshunov VM, Bodryagina LP, Pinegin BV. [Enterotoxigenic properties and antibiotic resistance of enterobacteria in postirradiation dysbacteriosis.] Zh Mikrobiol Epidemiol Immunobiol 1981; (11) 36-41.

11. Walker RI. The contribution of intestinal endotoxin to mortality in hosts with compromised resistance: a review. Exp Hematol 1978; 6: 172-184.

12. Geraci JP, Jackson KL, Mariano MS. Effect of Pseudomonas contamination or antibiotic decontamination of the GI tract on acute radiation lethality after neutron or $\gamma$-irradiation. Radiat Res 1985; 104: 395-405.

13. Brook I, Tom SP, Ledney GD. Quinolone and glycopeptide therapy for infection in mice following exposure to mixed-field neutron- $\gamma$-photon radiation. Int $J$ Radiat Biol 1993; 64: 771777.

14. Brook I, Ledney GD. Quinolone therapy in the prevention of endogenous and exogenous infection after irradiation. $J$ Antimicrob Chemother 1994; 33: 777-784.

15. Medical Research Council Committee on Effects of Ionizing Radiation: Lethality from acute and protracted radiation exposure in man. Int $J$ Radiat Biol Relat Stud Phys Chem Med 1984; 46: 209-217.

16. Gale RP. Immediate medical consequences of nuclear accidents. Lessons from Chernobyl. JAMA 1987; 258: 625-628.

17. Guskova AK, Baisogolov GD. Radiation sickness in man. Washington, DC, Technical Information Center AEC. 1973: 740.

18. Baranov AE, Shishkova TV, Protasova TG, Davydovskaia TI. [Combined antibiotic therapy of acute radiation disease in persons affected during the accident at the Chernobyl nuclear power station.] Antibiot Khimioter 1989; 34: 555-558.

19. Gus'kova AK, Baranov AE, Barabanova AV, Moiseev AA Piatkin EK. [Diagnosis, clinical picture and therapy of acute radiation disease in victims of the accident at the Chernobyl nuclear power station. I. Conditions of irradiation, dose levels, bone marrow syndrome and its therapy.] Ter Ark 1989; 61: 95103.

20. Mal'tsev VN, Korshunov VM, Strel'nikov VA, Ikonnikova TB, Kissina EV. [Bacteriotherapy of acute radiation sickness.] Radiobiologia 1978; 18: 757-760.

21. Korshunov VM, Pinegin BV, Mal'tsev VN, Kissina KV Ikonnikova TB. [Effect of antibiotics and bifidobacterium preparations on the intestinal microflora of mice irradiated with gamma quanta.] $\mathrm{Zh}$ Mikrobiol Epidemiol Immunobiol 1980 ; (7) 25-29.
22. Korshunov VM, Pinegin BV, Ivanova NP, Maltsev VN. [Effect of the combined use of antibiotic-resistant bifidobacteria and the corresponding antibiotics on the survivability of irradiated mice.] Zh Mikrobiol Epidemiol Immunobiol 1982; (5) 50-53.

23. Korshunov VM, Gladjko IA, Gindoman GA. Clinical and experimental ways of correction of intestinal microflora. Microecol Ther 1984; 14: 281-282.

24. Pinegin BV, Korshunov VM, Ivanova NP et al. [Use of the antibiotic-resistant bifidobacteria in the treatment of ulceronecrotic enterocolitis in young children.] $\mathrm{Zh}$ Mikrobiol Epidemiol Immunobiol 1983; (1) 59-64.

25. Pinegin BV, Korshunov VM, Glad'ko IA, Ivanova NP, Goncharova GI. [Joint use of antibiotics and antibiotic-resistant bifidobacteria in treating acute intestinal infections.] $\mathrm{Zh}$ Mikrobiol Epidemiol Immunobiol 1983; (5) 28-32.

26. Ruzaikina NI, Novokshonov AA, Zhoga VD, Ivanova NP, Korshunov VM, Gladko IA. [Efficacy of some bacterial preparations in the combined treatment of children with alimentary infections and nonspecific ulcerative colitis.] $V o p r$ Okhr Mat Det 1988; 9: 22-25.

27. Register of the radiation accidents and the clinical databaseresults of the Clinical Department of Institute for Biophysics, Ministry of Health of the Russian Federation, from 1952 to 1992. Institute of Biophysics, Moscow. 1992.

28. Pinegin BV, Tarabrina NP, Korshunov VM, Goncharova GI Ljannaja AM. Strain Bifidobacterium longum D4a200 used for the studies of colonisation abilities of exogenous bifidobacteria in microorganisms. USSR Patent 958493, Moscow. 1982.

29. Rasic JL, Kurmann JA. Bifidobacteria and their role: microbiological, nutritional, physiological, medical and technological aspects and bibliography. Basel: Birkbauser Verlag. 1982: 166.

30. Haenel $\mathrm{H}$. Human normal and abnormal gastrointestinal flora. Am J Clin Nutr 1970; 23: 1433-1439.

31. Lennette EH, Balows A, Hausler WJ, Truant J (eds). Manual of clinical microbiology, 3rd edn. Washington, DC, American Society for Microbiology. 1980

32. Liz'ko NN, Shilov VM. [Modern concepts of the makeup of intestinal microflora in healthy adults.] $Z h$ Mikrobiol Epidemiol Immunobiol 1979; (2) 36-41.

33. Finegold SM, Sutter VL, Matheisen GE. Normal indigenous intestinal flora. In: Hentges DJ (ed) Human intestinal microflora in health and disease. New York, Academic Press. 1983: 3-29.

34. Romanchuk LA, Elizbarashvili DA, Ginodman GA, Korshunov VM. [The effect of new antimicrobial preparations used in combination with complete gnotobiological isolation on the survivability and intestinal microflora of total-body irradiated mice.] Zh Mikrobiol Epidemiol Immunobiol 1991; (6) 4-6.

35. van der Waaij D. Colonization resistance of the digestive tract: mechanism and clinical consequences. Nahrung 1987; 31: $507-$ 517.

36. van der Waaij D. The colonization resistance of the digestive tract in experimental animals and its consequence for infection prevention, acquisition of new bacteria and the prevention of spread of bacteria between cage mates. In: van der Waaij $D$, Verhoef $\mathrm{J}$ (eds) New criteria for antimicrobial therapy: maintenance of digestive tract colonization resistance. Proceedings of a symposium, Utrecht, January 1979. (Excerpta Medica International Congress Series 477) Amsterdam-Oxford, Excerpta Medica. 1979: 43-53.

37. Conklin JJ, Walker RI, Hirsch EF. Current concepts in the management of radiation injuries and associated trauma. Surg Gynecol Obstet 1983; 156: 809-829.

38. Walker RC, Wright AJ. The quinolones. Mayo Clinic Proc 1987; 62: 1007-12.

39. Brook I, Ledney GD. The treatment of irradiated mice with polymicrobial infection caused by Bacteroides fragilis and Escherichia coli. J Antimicrob Chemother 1994; 33: 243-252.

40. Ivanov AA, Shal'nova GA, Ulanova AM et al. [Microbiological and immunological disorders in acute radiation disease patients, victims of the Chernobyl AES accident.] Vest Akad Med Nauk SSSR 1991; (8) 20-23. 